\title{
Effects of some organic materials on bicarbonate extractable phosphate content of soils having different $\mathrm{pH}$
}

\section{Nutullah Özdemir *, Ömrüm Tebessüm Kop Durmuș, İrem Zorba}

Ondokuz Mayıs University, Faculty of Agriculture, Department of Soil Science and Plant Nutrition, Samsun, Turkey

\section{Article Info}

Received : 19.01 .2016

Accepted : 07.04.2016

\begin{abstract}
This study was carried out to determine the effects of rice husk compost (RC), town waste compost (TW) and tobacco waste (TB) on bicarbonate extractable phosphate content (P) in soils having different $\mathrm{pH}$ levels under greenhouse conditions. Soil samples used in this study were taken from surfaces $(0-20 \mathrm{~cm})$ of agricultural fields around Samsun, Northern Anatolia. The experiment was conducted according to split plot design with four doses of organic matterials $(0$, 2.5, 5.0 and 7.5, \%). After a month of mixing organic matterials into soils, lettuce were grown in the medias. According to the results, RC, TW and TB applications into acidic (Tepecik), neutral (Kampüs) and alkaline (Çetinkaya) soils increased extractable P content. It was observed that effectiveness of organic matterials changed depend on soil reaction, type and dose of organic matterials. All organic wastes were more effective on increment of bicarbonate extractable phosphate content in neutral soil $\mathrm{pH}$ when compared the other soil $\mathrm{pH}$ levels.
\end{abstract}

Keywords: Compost, extractable phosphorus, organic residues, soil reaction.

(C) 2016 Federation of Eurasian Soil Science Societies. All rights reserved

\section{Introduction}

Organic matter concentration of soils is a dynamic property and affects both soil physical and chemical properties and its overall sustainability. It is known that adding organic matter to soil develop soil physical conditions and regulate chemical conditions (Anderson et al., 1990; Gajic et al., 2006; Demir and Gülser, 2015). Many studies showed that the amelioration of soil physical (Gülser and Candemir, 2006; Yakupoglu and Ozdemir, 2012) and chemical (Özdemir, 1993; Haynes, 2000) properties largley based on increaments of organic carbon in the soils with using organic wastes. Soil organic matter is an essential but transient component of the soil that controls many physical, chemical and biological properties of the soil (Carter, 1996; Kizılkaya, 2008). In the formation of fertile soil, organic substances play a direct role as sources of plant nutrients which are liberated in available form during mineralization. The incorporation of agricultural wastes such as; poultry manure and cow dung, with rock phosphate significantly improved the release phosphorus and raised crop yields (Akande et al., 2005; Akande et al., 2008; Agyarko et al., 2015).

Organic matter level of soils is mostly low in Turkey (Kizllkaya, 2004). This is a big problem especially in semi-arid regions. To increase the level of organic material, the most common approach is to apply different organic matter sources to cultivcated soils. The use of waste in agriculture, forestry and land reclamation has been increasingly identified as an important issue for soil fertility, conservation and residual disposal (Aslantas et al., 2010; Angin et al., 2013). Using waste in agriculture helps not only dispose these materials economically, but also reduces negative effects on the environment and improve soil quality parameters. Soil quality can be improved with the addition of wastes, which contains appropriate levels of organic matter (Candemir and Gülser, 2010). Organic conditioner application into soils improves not only the soil structure

\footnotetext{
${ }^{*}$ Corresponding author.

Ondokuz Mayıs University, Faculty of Agriculture, Department of Soil Science and Plant Nutrition, 55139 Samsun, Turkey

Tel.: +903623121919

E-mail address: nutullah@omu.edu.tr 
but also the nutrient quantity and availability in soils (Sahin et al., 2008; Demir and Gülser, 2015; Gülser et al., 2015).

This study was carried out to determine the effects of rice husk compost (RC), town waste compost (TW) and tobacco waste (TB) applications on extractable P content in soils having different pH levels .

\section{Material and Methods}

In this study, disturbed surface soil samples (0-20 cm depth) were taken from agricultural lands aroud Samsun, Northern Anatolia. Soil reaction was taken into account for soil sampling from neutral, acidic and alkaline soil series (Tepecik, TP; Kampus, KP Cetinkaya, CT, respectively). The rice husk compost (RC), town waste compost (TW) and tobacco waste (TB) were obtained from different institutions. Some properties of organic materials are given in Table 1.

Table 1. Some properties of organic matter sources

\begin{tabular}{lrrrr}
\hline Organic Materials & OC, $\%$ & OM, \% & $\mathrm{N}, \%$ & 1.97 \\
\hline Tobacco waste & 38.40 & 66.20 & 19.49 \\
Rice husk compost & 9.91 & 17.08 & 0.88 & 11.26 \\
Town waste compost & 17.86 & 30.79 & 1.55 & 11.52 \\
\hline
\end{tabular}

Soil samples were treated with four different levels of organic matterials $(0,2.5 \%, 5.0 \%$, and $7.5 \%$ dry weight basis) and soil mixtures were put into plastic pots with a volume of $4500 \mathrm{~cm}^{3}$. Each treatment was replicated two times in a split block design ( 3 soils $\times 3$ organic matterials $\times 4$ application doses $\times 2$ replications). All pots were incubated at field capacity moisture content and $20^{\circ} \mathrm{C}$ for 4 weeks under greenhouse conditions. After the one month of incubation period, lettuce plant was grown in the pots. At the end of the greenhouse study, soil samples were taken for analyses. Some physical and chemical properties of soils were determined as fallows; soil organic matter content by the modified Walkley-Black method (Nelson and Somners, 1982); soil texture by hydrometer method (Bouyoucos, 1962); pH in soil-water suspension (1/2.5 w:v) by pH meter (McLean, 1982), EC in the same soil suspension by EC meter (Rhoades, 1982), lime content by Scheibler calcimeter method (Nelson, 1982). Due to increasing soil pH after the organic matter applications, phosphate contents of soils were determined by sodium bicarbonate $\left(0.5 \mathrm{M} \mathrm{NaHCO}_{3}\right.$ extractable) method (Olsen and Somners, 1982). Data analyses were done using SPSS package programe.

\section{Results and Discussion}

\section{Soil properties}

Some physical and chemical soil properties are given in Table 2. According to the results, soil properties can be summarized as; moderately fine and fine in texture, moderate in organic matter content, low in total lime content, moderately acid, neutral and moderately alkaline in pH (Soil Survey Division Staff, 1993).

Table 2. Some physical and chemical properties of the soils

\begin{tabular}{lccc}
\hline Parameters & & Soil series & Cetinkaya (ÇT) \\
\cline { 2 - 4 } & Tepecik (TP) & Kampus (KP) & 15.0 \\
\hline Clay, \% & 39.4 & 40.2 & 39.4 \\
Silt, \% & 34.1 & 25.6 & 45.6 \\
Sand, \% & 26.5 & 34.2 & Loam \\
Texture & Clay Loam & Clay & 8.33 \\
pH $(1: 2.5)$ & 5.60 & 7.00 & 0.56 \\
EC, dS/m & 0.42 & 2.40 & 0.56 \\
CaCO,$\%$ & 1.19 & 2.40 & 1.31 \\
OM, \% & 2.40 & 1.13 & \\
\hline
\end{tabular}

\section{Changes in soil $\mathrm{pH}$ values}

Application of organic materials on soil pH are given in Table 3. While soil pH values in Tepecik and Kampüs soils increased by the organic waste application, soil $\mathrm{pH}$ values in Çetinkaya soil decreased. Mean soil $\mathrm{pH}$ varied between 6.53 and 6.82 in Tepecik Soil, between 7.04 and 7.37 in Kampüs Soil and between 7.45 and 7.95 in Çetinkaya Soil by the application of organic materials. Except the $2.5 \%$ application doses in Tepecik soil, soil $\mathrm{pH}$ values varied around neutral and moderately alkaline after the organic waste treatments. Candemir and Gülser (2010) reported that tobacco waste application into a clay soil increased soil pH after 16, 23 and 30 months of the application in a field study. However, Demir and Gülser (2015) reported that 3, 6 and $9 \%$ applications of rice husk compost into moderately alkaline soil decreased soil $\mathrm{pH}$. 
Table 3. Effect of soil organic materials on soil reactions (pH).

\begin{tabular}{lcccc}
\hline & Dosses & Tepecik & Kampüs & Çetinkaya \\
\hline Control & 0 & 5.91 & 6.89 & 8.12 \\
\hline \multirow{2}{*}{ Town waste compost } & $2.5 \%$ & 6.48 & 7.38 & 7.96 \\
& $5.0 \%$ & 6.93 & 7.40 & 7.76 \\
Mean & $7.5 \%$ & 6.87 & 7.33 & 7.73 \\
\hline \multirow{2}{*}{ Tobacco waste } & & 6.76 & 7.37 & 7.82 \\
& $2.5 \%$ & 6.46 & 7.00 & 7.61 \\
Mean & $5.0 \%$ & 6.73 & 7.04 & 7.38 \\
Rice husk compost & $7.5 \%$ & 7.28 & 7.08 & 7.36 \\
& & 6.82 & 7.04 & 7.45 \\
\hline Mean & $2.5 \%$ & 6.38 & 7.11 & 8.03 \\
\hline
\end{tabular}

\section{Bicarbonate extractable phosphate contents of soils}

The effects of amendments on the bicarbonate extractable $P$ values changed depend on the type and rates of organic materials in each soil series (Figure 1). It was observed that the bicarbonate extractable P values of all soils increased significantly depending on soil $\mathrm{pH}$ and type of organic materials. Bicarbonate extractable $\mathrm{P}$ values in the control soils were $3.02 \mathrm{ppm}$ for moderately acidic Tepecik, $11.21 \mathrm{ppm}$ in neutral Kurupelit and $9.20 \mathrm{ppm}$ moderately alkaline Çetinkaya soil series. (Figure 1). According to the P mean values of organic materials compared with the control, all organic treatments were more effective on neutral or Kampüs soil. The percentage increases in mean $\mathrm{P}$ values by the application of organic materials in moderately acidic, neutral and moderately alkaline soils over the control were found to be TB > TW > RC $(69,56$ and $49 \%$, respectively) in Tepecik soil, TB $>$ TW $>$ RC $(52,43$ and $29 \%$, respectively) in Kampüs soil and TB $>$ TW $>$ RC (59, 31 and $27 \%$, respectively) in Çetinkaya soil series. According to the control soils, bicarbonate extractable mean P contents of Tepecik, Kurupelit and Çetinkaya soil series significantly increased 57.9, 41.8 and 39.1\%, respectively (Table 4). Demir and Gülser (2015) reported that application of $9 \%$ rice husk compost into soil increased available P content from 60 to 120 ppm, significantly.

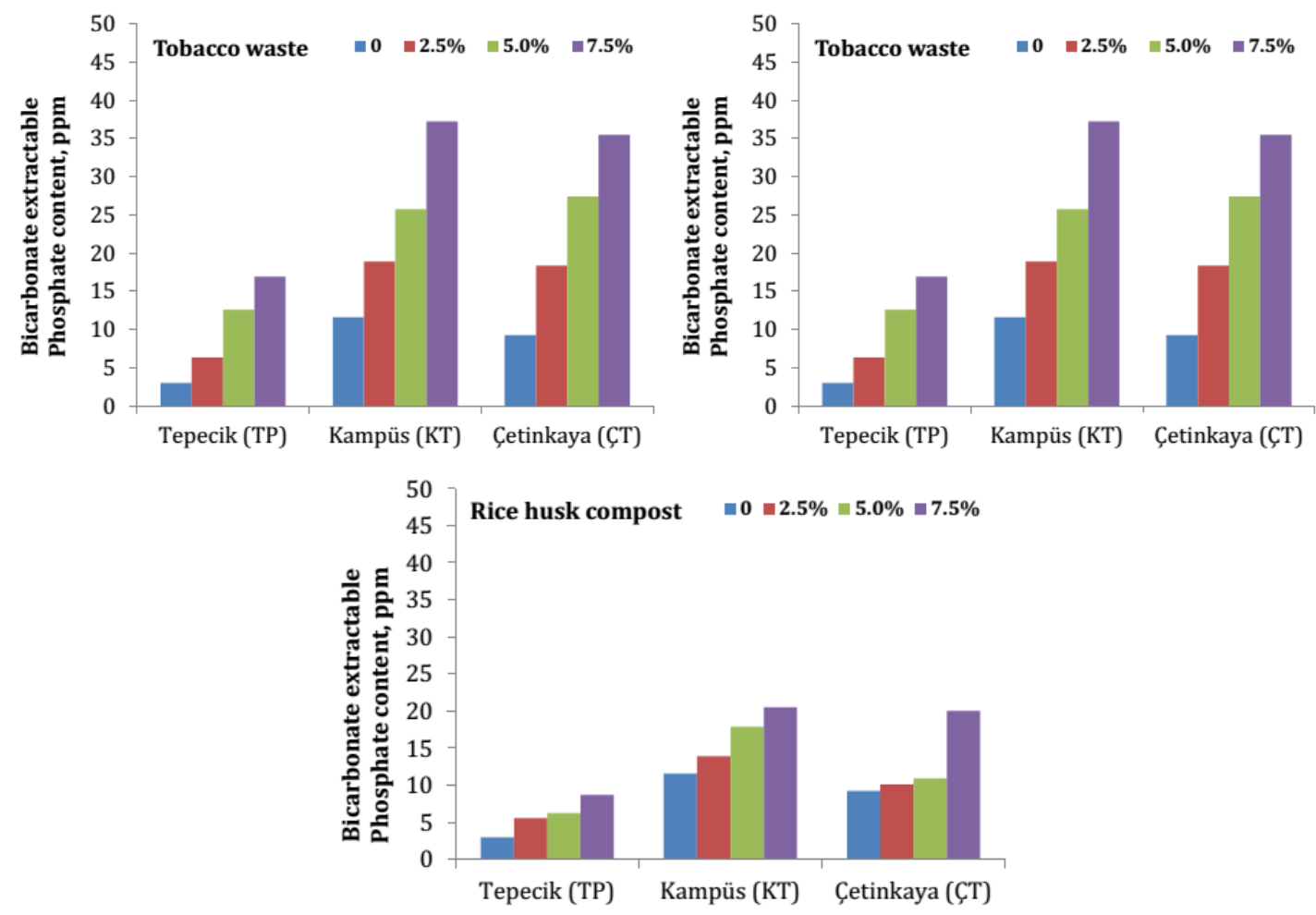

Figure 1. The effects of organic materials at different application rates on Tepecik (TP), Kurupelit (KP) and Çetinkaya (ÇT) soil series $(\mathrm{P}<0.01)$. 
According to the statistical analysis of data given in Table 4, bicarbonate extractable $\mathrm{P}$ values were significantly different in soil series at 0.01 level. On the other hand, bicarbonate extractable mean $\mathrm{P}$ values were also significant for different organic materials and application doses at 0.01 level.

Table 4. Mean values of bicarbonate extractable phosphate content at different soil series, organic material treatments, and application rates.

\begin{tabular}{|c|c|c|c|c|}
\hline Soil Series & & $\begin{array}{l}\text { Tepecik } \\
7.51 \mathrm{a}^{*}\end{array}$ & $\begin{array}{l}\text { Kampüs } \\
19.79 \text { c }\end{array}$ & $\begin{array}{l}\text { Çetinkaya } \\
16.13 \mathrm{~b}\end{array}$ \\
\hline Organic Matterials & & $\begin{array}{c}\text { Town waste comp. } \\
13.36 \mathrm{~b}\end{array}$ & $\begin{array}{c}\text { Tobacco waste } \\
18.57 \text { c }\end{array}$ & $\begin{array}{c}\text { Rice husk comp. } \\
11.49 \mathrm{a}\end{array}$ \\
\hline Application Rates & $\begin{array}{c}0 \\
7.97 \mathrm{a}\end{array}$ & $\begin{array}{c}2.5 \% \\
11.95 \mathrm{~b}\end{array}$ & $\begin{array}{c}5.0 \% \\
16.64 \mathrm{c}\end{array}$ & $\begin{array}{c}7.5 \% \\
21.35 \mathrm{~d}\end{array}$ \\
\hline
\end{tabular}

\section{Conclusion}

The results can be summarized as; organic material treatments generally increased the bicarbonate extractable $\mathrm{P}$ contents of soils having different $\mathrm{pH}$ levels. Effectiveness of the organic materials varied depends on soil reaction, type and application rates of organic materials. The effectiveness of the rice husk compost on bicarbonate extractable $P$ content of soil had considerably lower than the other organic materials. The highest effect on the $\mathrm{P}$ content was obtained with the highest rate of tobacco waste application in Kurupelit soil having neutral $\mathrm{pH}$. All organic wastes were more effective on the increment of $\mathrm{P}$ content in neutral soil pH when compared the other soil pH levels.

\section{References}

Agyarko, K., Abunyewa, A.A., Asiedu, E.K., Heva, E., 2015. Dissolution of rock phosphate in animal manure soil amendment and lettuce growth. Eurasian Journal of Soil Science 5(2): 84-88.

Akande, M.O., Adedira, J.A., Oluwatoyinbo, F. I., 2005. Effect of rock phosphate amended with poultry manure on soil available $\mathrm{P}$ and yield of maize and cowpea. African Journal of Biotechnology 4(5): 444-448.

Akande, M.O., Oluwatoyinbo, F. I., Kayode, C.O., Olowookere, F.A., 2008. Effects of Ogun phosphate rock amended with different levels of cowdung on the growth and yield of maize okra intercrop relayed with cowpea. African Journal of Biotechnology 7 (17): 3039-3043.

Anderson, S.H., Gantzer, C.J., Brown, J.R., 1990. Soil physical properties after 100 years of continuous cultivation. Journal of the Soil and Water Conservation 45(1): 117-121.

Angin, I., Aksakal, E. L., Oztas, T., Hanay, A., 2013. Effects of municipal solid waste compost (MSWC) application on certain physical properties of soils subjected to freeze-thaw. Soil and Tillage Research 130: 58-61.

Aslantas, R., Angin, I., Karakurt, H., Kose, M., 2010. Vegetative and pomological changes of sour cherry as affected by sewage sludge application. Bulgarian Journal of Agricultural Science 16(6): 740-747.

Bouyoucos, G.J., 1962. A recalibration of the hydrometer method for making mechanical analysis of the soils. Agronomy Journal 54 (5):419-434.

Candemir, F., Gülser, C. 2010. Effects of different agricultural wastes on some soil quality indexes at clay and loamy sand fields. Communications in Soil Science and Plant Analysis 42(1): 13-28.

Carter, M. R., (1996). Analysis of soil organic matter storage in agroecosystems. In Carter, M. R., Stewart, B. A., (eds): Structure and organic matter storage in agricultural soils, pp. 3-14. CRC Pres, Inc.

Demir, Z., Gülser, C. 2015. Effects of rice husk compost application on soil quality parameters in greenhouse conditions. Eurasian Journal of Soil Science 4(3): 185-190.

Gajic, B., Dugalic, G., Djurovic, N., 2006. Comparison of soil organic matter content, aggregate composition and water stability of gleyic fluvisol from adjacent forest and cultivated areas. Agronomy Research 4(2): 499-508.

Gülser, C., Candemir, F., 2006. Using pedotransfer functions to predict aggregation and permeability by hazelnut husk application. 18th International Soil Meeting (ISM) on "Soil Sustaining Life on Earth, Managing Soil and Technology" May, 22-26, Şanlıurfa Turkey, Proceedings Vol. (II), 847-852.

Gülser, C., Kızılkaya, R., Așkın, T., Ekberli, İ., 2015. Changes in soil quality by compost and hazelnut husk applications in a Hazelnut Orchard. Compost Science \& Utilization 23(3): 135-141.

Haynes, R.J., 2000. Interactions between soil organic matter status, cropping history, method of quantification and sample pretreatment and their effects on measured aggregate stability. Biology and Fertility of Soils 30(4): 270275.

Kızılkaya, R., 2004. $\mathrm{Cu}$ and $\mathrm{Zn}$ accumulation in earthworm Lumbricus terrestris L. in sewage sludge amended soil and fractions of $\mathrm{Cu}$ and $\mathrm{Zn}$ in casts and surrounding soil. Ecological Engineering 22(2): 141-151.

Kızılkaya, R., 2008. Dehydrogenase activity in Lumbricus terrestris casts and surrounding soil affected by addition of different organic wastes and Zn. Bioresource Technology 99(5): 946-953. 
McLean, E.0., 1982. Soil pH and lime requirement. In: Methods of Soil Analysis, Part 2, Chemical and microbiological properties, Second Edition. Number 9, Page, A.L., Keeney, D. R., Baker, D.E., Miller, R.H., Ellis, R. Jr., Rhoades, J.D. (Eds.). ASA-SSSA, Madison, Wisconsin, USA. pp.199-224.

Nelson, R.E., 1982. Carbonate and gypsum. In: Methods of Soil Analysis, Part 2, Chemical and microbiological properties, Second Edition. Number 9, Page, A.L., Keeney, D. R., Baker, D.E., Miller, R.H., Ellis, R. Jr., Rhoades, J.D. (Eds.). ASASSSA, Madison, Wisconsin, USA. pp. 181-198.

Nelson, D.W., Sommers, L.E., 1982. Total carbon, organic carbon, and organic matter. In: Methods of soil analysis, Part 2, Chemical and microbiological properties, Second Edition. Number 9, Page, A.L., Keeney, D. R., Baker, D.E., Miller, R.H., Ellis, R. Jr., Rhoades, J.D. (Eds.). ASA-SSSA, Madison, Wisconsin, USA. pp.539-580.

Olsen, S.R., Sommers, L.E., 1982. Phosphorus. In: Methods of soil analysis, Part 2, Chemical and microbiological properties, Second Edition. Number 9, Page, A.L., Keeney, D. R., Baker, D.E., Miller, R.H., Ellis, R. Jr., Rhoades, J.D. (Eds.). ASA-SSSA, Madison, Wisconsin, USA. pp.403-448.

Özdemir, N., 1993. Effects of admixturing organic residues on structure stability and erodibility of soils. Ataturk University, Journal of the Faculty of Agriculture 24 (1):75-90.

Rhoades, J.D., 1982. Soluble Salts. In: Methods of soil analysis, Part 2, chemical and microbiological properties, Second Edition. Number 9, Page, A.L., Keeney, D. R., Baker, D.E., Miller, R.H., Ellis, R. Jr., Rhoades, J.D. (Eds.). ASA-SSSA, Madison, Wisconsin, USA. pp.167-180.

Sahin, U., Angin, I., Kiziloglu, F.M., 2008. Effect of freezing and thawing processes on some physical properties of salinesodic soils mixed with sewage sludge or fly ash. Soil and Tillage Research 99: 254-260.

Soil Survey Division Staff. 1993. Soil survey manual. Soil Conservation Service. U.S. Department of Agriculture Handbook 18. USA.

Yakupoglu, T., Ozdemir, N., 2012.. Influence of some organic amendment materials on total porosity of an eroded soil. Archives of Agronomy and Soil Science 58(S1): S195-S200. 